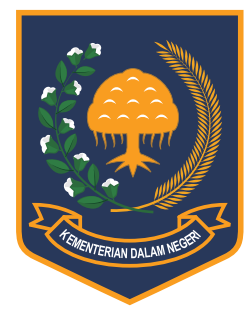

Jurnal Bina Praja 8 (2) (2016): 221-230

Jurnal Bina Praja

e-ISSN: 2503-3360 | p-ISSN: 2085-4323

Accreditation Number

735/AU2/P2MI-LIPI/04/2016

http://jurnal.kemendagri.go.id/index.php/jbp/index

\title{
Poverty AND Human Rights: NeW Direction in Poverty ERAdication
}

\author{
Pihri Buhaerah ${ }^{1, *}$ \\ ${ }^{1}$ Sub-Commission of Study and Research of National Commission of Human Rights \\ of the Republic of Indonesia \\ Jl. Latuharhary No. 4B, Menteng, Jakarta Pusat-10310
}

Received: 20 June 2016; Accepted: 8 October 2016; Published online: 30 November 2016

DOI: $10.21787 /$ jbp. $08.2016 .221-230$

\begin{abstract}
The purpose of this paper is to support the argument that poverty is multidimensional and part of human rights concern. In doing so, this paper uses relevant literature review on poverty issues. This paper finds that the capability approach is a useful conceptual framework to link conventional approach with human rights and support the argument that poverty is multidimensional. Under this perspective, there are two prerequisites cases of non-fulfillment of human rights can be counted as poverty, namely (i) the human rights involved must be those that correspond to the capabilities that are considered basic by a given society; and (ii) inadequate command over economic resources must play a role in the causal chain leading to the non-fulfillment of human rights. Furthermore, there are three different ways in which human rights can be relevant to poverty: constitutive relevance, instrumental relevance, and constraint-based relevance.
\end{abstract}

Keywords: poverty, income, human rights, capability.

\section{INTRODUCTION}

The report of Oxford Poverty and Human Development Initiative entitled "Global Multidimensional Poverty Index 2014" stated that from the total population of 5.4 billion being surveyed, there are 1.6 billion people or around $30 \%$ still live in multidimensional poverty. From the total of 1.6 billion, $52 \%$ live in South Asia and $29 \%$ in Sub-Sahara, Africa. The irony is, $71 \%$ of the poor group live in a middle-income country. The report also noted that $85 \%$ of the poor live in rural area and the rest $15 \%$ live in urban area.

In the ASEAN region, the World Bank reported that Indonesia is a country which percentage of the poor is classified as high. According to the data from the World Bank (2016), with the standard of 1.90 USD per day, the percentage of the poor in Indonesia is reported to be $15.90 \%$. Meanwhile, if the standard of 3.1 USD per day, then the percentage of Indonesia soars into $41.67 \%$. The data from the World Bank also showed that the difference of percentage of poor society between Indonesia and the Philippines is not too far. It's a different case if compared to
Malaysia or Thailand. By using the standard of 1.9 USD per day, the percentages of the poor in Malaysia and Thailand consecutively are only 0.28 and 0.06 . Meanwhile, if the standard of 3.1 USD per day is used, the percentages of the poor in Malaysia and Thailand are 2.71 and 1.23 each.

In contrast with the World Bank, the statistical data of BPS showed that the provinces with the highest poverty population percentage are Papua (27.80\%) and West Papua (26.26\%). Meanwhile, the provinces of DKI Jakarta and Bali are the areas with the lowest poor population percentage in Indonesia, each amounted to $4.09 \%$ and $4.76 \%$. The percentage of the poor is mostly concentrated in rural areas $(13.76 \%)$ if compared to urban areas (8.16\%). Interestingly, the data from BPS also showed that the rate of decline in poverty which decreased from 4.4 percent per year within the periods of $2006-2010$ to be $1.4 \%$ per year within the period of 2011-2014.

The slowing pace of poverty reduction is, of course, regrettable. Because the poverty eradication budget from year to year kept creeping up. As an

\footnotetext{
* Corresponding Author

Phone : +6282123280579

Email : pihri.buhaerah@gmail.com
} 
illustration, in 2009, the poverty alleviation budget was 79.9 trillion IDR (Ministry of Finance, 2015). Meanwhile, in 2014, the budget allocation for poverty eradication soared to 134.5 trillion IDR. That is when compared to the 2010 budget, the budget of poverty in 2015 surged by $68 \%$ since it reached 137.6 trillion IDR. Unfortunately, the increase in poverty budget is not directly proportional to the rate of poverty reduction. This can be seen from the cost to alleviate someone from poverty, which becomes more inefficient from year to year. The study result of Budiantoro and Martha (2012) revealed that in 2012, required a budget of 100 million IDR to alleviate a person from poverty. While in fact, in 2008 alone, the budget to alleviate one's poverty is still around 30 million IDR (Budiantoro \& Martha, 2011).

The slow pace of poverty reduction is also due to the poverty eradication that is not integrated with the national development strategy. For example, the construction of large-scale infrastructure such as ports, airports, highways, railroads, and the like is identical to the forcible evictions which potentially leads to farmers and fishermen become poorer than before. Not to mention that the compensation scheme given to those whose land affected by infrastructure development projects seems perfunctory. This indicates that the practices in the field of development will potentially increase the number of poor people rather than increase the degree of the welfare of the marginalized groups such as farmers and fishermen.

Another illustration is the poverty eradication program formulated by the National Team to Accelerate Poverty Eradication (TNP2K), such as a group for poverty eradication programs based on community empowerment (Cluster II) and based on the empowerment of micro and small economic activities (Cluster III), does not touch the importance of the program of redistribution and land reallocation through agrarian reform. Such community empowerment program generally only contains a group of programs that are believed to help the poor out of poverty, but without the leap to become the new middle class (Saparini, 2012). Without strategy and policy of asset protection towards marginalized groups, especially farmers, and fishermen, such poverty eradication program clearly would not have a significant impact in breaking the chain of structural poverty in Indonesia.

One major factor of the ineffectiveness of some poverty programs today is considered to be a wrong point of view of policy makers in formulating the fundamental rights of the poor as citizens and government's obligation as resource managers. Poverty eradication is not simply a matter of the program, procedural, mechanical, and technical but must also move towards improving the human dignity of the poor. That is, it takes a broader meaning of poverty, but without ignoring the constraints of poverty as a matter of economic resources constraints.

Therefore, the strategies, policies, and programs of poverty eradication today must be reviewed using more humane approach so that the trend of the slowdown in the rate of poverty reduction does not continue in the days to come. Unfortunately, the approach to poverty these days still calculates poverty in terms of income or consumption. Most of the discussions among academics and development practitioners in international organizations like the World Bank and UN agencies, which focus of work is associated with poverty, use the income approach either explicitly or implicitly. The approach is focused on whether the household or individual has sufficient resources to meet their basic needs (Haughton \& Kandker, 2009).

In Indonesia, Central Bureau of Statistics (BPS) estimates poverty at the national level based on Susenas Panel Modul Konsumsi (National Economy Social Survey on Consumption Module Panel). That is, poverty is seen as an economic inability to meet the basic needs of food and non-food which is measured from the expenditure side. This approach sees poverty as an economic inability to meet basic needs as measured from the expenditure side. In measuring the number of poor people in Indonesia, BPS uses poverty line. Therefore, BPS defines the poor as those who have an average expenditure per capita per month below the poverty line.

The similar method is used by BPS to calculate the poverty line consisting of two components, namely the Food Poverty Line (FPL) and the NonFood Poverty Line (NFPL). FPL is a minimum food expenditure, which is synchronized with 2,100 calories per capita per day. While NFPL is a minimum requirement for housing, clothing, education, health and other basic needs. In addition, BPS is also calculating the poverty line separately for urban and rural areas.

It indicates that the policy makers' perspective towards the poor has not changed significantly. It is not surprising that the impact of the various poverty eradication policies does not touch many fundamental problems of poverty. Thus, it takes a change in the approach to poverty which could provide a good understanding of the poor and all the problems that they face every day. Even so, dealing with the problems faced by the poor from the view of the poor is often different in the logic and the minds of policy makers or development practitioners. Another problem is that the number of concepts and theories of social, political, and developing economies are still rarely focusing explicitly on the promotion of the dignity of the poor.

Interestingly, it is only the theory of human 
rights (HAM) which expressly makes a fundamental freedom, dignity, and human dignity as the center of the analysis. Therefore, the development of definitions, conceptual frameworks, and poverty eradication strategy from the perspective of human rights to be interesting and important to be examined. Upon that basis, some issues that need to be addressed in the study of this thinking among others are how the definition of poverty from a human rights perspective, how the conceptual framework of poverty according to a human rights perspective, and how the strategy of poverty eradication in human rights perspective.

\section{METHOD}

On that basis, then this study will try to uncover and describe the dynamics of the development of poverty thinking and a number of issues in the concept of poverty these days using a human rights standpoint. Therefore, this study will present a number of ideas from the experts on poverty and institutions that pay attention to the problem of poverty. The review of the development of the concept of poverty is done through a literature review of the previous research work and reports that have been published in books, journals, policy reviews, working papers, and other documents related to the focus of this study.

\section{RESULT AND DISCUSSION}

\section{A. Poverty Discourse}

The poverty measurement using income or consumption approach is already a tradition handed down primarily for development practitioners in developing countries. Of the two approaches, the expenditure approach is more widely adopted in developing countries including Indonesia. A number of practical reasons raised, such as the level of consumption are more stable than the level of income in measuring the level of people's living standards. Another practical reason is that the level of consumption is more easily and accurately measured in countries with relatively low levels of participation in the formal labor market (World Bank, 2015).

Therefore, poverty is usually measured by comparing individual income or consumption with poverty line and how well the consumption of the population on a number of goods that are the most basic needs of the population (Haughton \& Kandker, 2009). Income approach sees poverty as a lack of income (or consumption). This kind of poverty is generally defined by the poverty line, which is the minimum income required to meet basic minimum needs.

According to this approach, conceptually, poverty can be divided into two types: absolute poverty and relative poverty. The concept of absolute poverty is intended to measure the level of minimum income sufficient to meet the basic physical needs of each person both for food and non-food groups. This concept typically uses the international poverty line (such as 1 USD or 2 USD per day) as the minimum income standard that is used to meet the basic physical needs.

Related to that, the World Bank set the absolute poverty line of 1 USD and 2 USD PPP (Purchasing Power Parity) per day. The absolute poverty line is intended to compare poverty rates between countries or between regions. The poverty line is usually used as an initial step in assessing the progress made in reducing poverty at the global level. PPP conversion rate is generally defined as the amount of rupiah that must be spent to buy a number of needs for goods and services in which the same number can be purchased for 1 USD in the United States.

The concept of relative poverty emerged as the difficulty of determining the level of the basic needs or minimum living standard that is local. Therefore, in contrast to absolute poverty, relative poverty assessment method uses an assessment standard and determined subjectively. That is, the assessment standard adapted to the socio-economic conditions of a country or region such as the price level, the level of income per capita, purchasing power, culture, consumption preferences, the level of education, and others.

The general approach to poverty (income or consumption based) usually depart on the thesis that believes that someone wants a decent income to meet their needs. Kakwani (2006) describes that the approach assumes that with sufficient income, then someone will have possession of the goods to be consumed. That is, the higher a person's income, the greater the degree of their control over the consumer goods (Kakwani, 2006). Therefore, the possession of the goods and services, including the provision of facilities and infrastructure, becomes important to make a better life (Kakwani, 2006). Thus, according to the income or consumptionbased approach, the possession of a commodity or prosperity become an important indication of someone's quality of life.

However, the concept and the definition are continuously under the challenge from economists, academics, civil society organizations, and even the United Nations development agencies. The reason is well-being or living standard is basically not only in the possession of the commodity. The possession of commodities or satisfaction arising from these commodities is also just a tool. The most important thing is actually what benefits that can be taken by a person of such goods. Therefore, poverty should 
be seen as a lack of basic skills. Not only as low income, which is a standard criterion for measuring poverty today. In short, the capability to function is a parameter that determines a person's status as a poor person (Sen, 1999).

In this regard, Sen (1999) describes three reasons for the weakness of the income approach. Firstly, poverty is identified as the reduction of ability to function is intrinsically important (unlike the low income, the only significant instrumental). Secondly, there is an influence on the reduction of ability on real poverty due to low income (income is not the only instrument that enhances the ability). Third, the instrumental relationship between low income with low abilities vary among communities, families, and individuals (the revenue impact on the ability to be uncertain and conditional).

On that basis, income is not a factor that determines a person in need to be poor or not. Although we cannot deny that the shortfall in revenue can come up with other forms of deprivation, but the outlook does not necessarily associate revenue shortfalls as poverty. The reason is, a person may experience the life of the needy despite having sufficient mastery over resources. There are still many other forms of deficiencies that can help us understand the dimensions of poverty as a whole, such as unemployment, poor health, lack of access to clean water and sanitation, lack of education, inequality, social exclusion, social collapse, the lack of social security/ protection, etc.

On the other side, income or consumptionbased approach as described previously still leaves a number of questions for Ravi Kanbur, an economist at Cornell University-USA. According to Kanbur (2006), income or consumption-based approach can be relied on if the poor population measured is fixed or unchanging. If the population of the poor is changing or up and down, then the measurement standard of poverty based on income or consumption tends to conclude uncertainty (Kanbur, 2006).

Meanwhile, the United Nations Development Programme (UNDP) in its 1997 Human Development Report defines poverty as shortcomings in terms of value or anything that makes a person can do or be something to be desired (UNDP, 2000). The term human poverty created to distinguish the meaning of deficiencies in a broad sense with poverty in the narrow sense, which is confined to the mere lack of income or consumption (UNDP, 2000). Furthermore, the 2000 Human Development Report also describes in depth how poverty has a wider meaning than just a lack of income. Poverty is a manifestation of a shortage in many ways and dimensions. If income is not the total of the dimensions of human life, the lack of income can not be used as a measure of the total number of human deficiencies (UNDP, 2000).
Table 1.

Evolution of Definition and Measurement of Poverty 1950s-2000s

\begin{tabular}{ccc} 
Period & Poverty Concept & Poverty Measurement \\
1960 s & Economy & GDP per capita growth \\
\hline 1970 s & $\begin{array}{c}\text { Basic Needs } \\
\text { (including economy) }\end{array}$ & $\begin{array}{c}\text { GDP per capita growth } \\
\text { and basic need goods }\end{array}$ \\
\hline 1980 s & Economy & GDP per capita \\
\hline 1990 s & $\begin{array}{c}\text { Human Development } \\
\text { (including economy) }\end{array}$ & $\begin{array}{c}\text { UNDP Human } \\
\text { Development Index }\end{array}$ \\
\hline 2000s & Multidimensional & $\begin{array}{c}\text { Millennium Development } \\
\text { "freals (MDGs) }\end{array}$ \\
\hline
\end{tabular}

Source: Sumner, 2007

Table 1 shows how were the development of poverty thinking and measure since the 1960s up to the 2000s period. Interestingly, the discourse on the concept and definition is precisely moving towards recognition of the importance of the presence of human rights principles and standards in the conception of poverty. What is also interesting in table 1 is the occurrence of poverty paradigm shifting that was merely an economic phenomenon to be wider by conceptualizing poverty that is multidimensional or from consideration that it was simply an indicator of complementary development policies to become the main purpose, or the fulfillment of needs (period 1960-1980) to become the fulfillment of human rights (the 1990s-2000s).

The above paradigm shift confirms that the approach of income or consumption that are commonly used today, whether we like it or not, is acknowledged to contain some fundamental weaknesses that need to be expanded in order to get an overview of poverty more completely and comprehensively. Interestingly, the Human Development Report of 2000 explicitly recognized the importance of human rights in the understanding of multidimensional poverty by defining poverty as a violation of freedom, and that the elimination of poverty should be seen as an act of fulfillment of the fundamental guarantees and human rights.

\section{B. Human Rights-Based Poverty}

\section{1) Definition of Rights and Needs}

As a first step towards a conception of the right human rights-based poverty, it takes a true understanding in distinguishing between the rights and the needs. Human rights are literally defined as basic rights inherent in the individual because he is a human being (Donnelly, 2006). This means that human rights are a collection of the most fundamental rights needed by everyone to develop and participate fully in society. Such rights are universal because they are inherent to all human beings wherever they are. Such rights cannot be 
revoked and separated between civil and political rights, and economic, social, and cultural rights. (Donnelly, 2006).

Furthermore, right is something that can be prosecuted and contains the obligation imposed on the government. Right is widely characterized as legitimate claims that give rise to correlative obligations or responsibilities (Moser, 2005). Having the right means legally entitled to claim against several people, groups, or organizations, such as social or economic institution, country, or the international community (Moser, 2005). State, in turn, has an obligation or duty to assist in ensuring the rights holders of those rights (Moser, 2005). As an illustration, $A$ has the right to the $B$ in relation to $C$, where $A$ is the holder of the rights, $B$ is the executor of the obligation, and $\mathrm{C}$ is the object or the final purpose of rights (Moser, 2005).

On the contrary, the need is an aspiration that may be legal by law but does not necessarily contains government obligation to make it happen. Therefore, satisfaction fulfillment cannot be enforced. In the context of the needs-based approach, the State considered its duty if it has to do something without having to guarantee the enjoyment of human rights, for instance through the maximization of available resources in a sustainable and meaningful manner. Despite the needs-based approach also recognizes the importance of community involvement in the process of poverty eradication, but this approach still does not touch the root of the problem in the process of poverty reduction since public participation is seen merely as a complementary requirement. This is what makes the rights-based approach is more potent than the need-based approach because it guarantees policies and strategies for poverty reduction and not just there.

Meanwhile, the needs-based approach puts strategies, policies, and poverty eradication program to aim more at giving and providing services for basic needs. Thus, society is placed as the recipient of "aid" and the State as the giver of "aid". In other words, poverty reduction strategy is a "scheme of compassion" or "charity package" from the state to the citizen. In addition, the needs-based approach does not make the root of problems in development, such as the paradigm of policies, institutions, rules, and regulations that are not in favor on the expansion of capabilities and freedoms of the poor, as the focus of attention in poverty eradication strategies.

The needs-based approach also does not explain in detail the responsible stakeholders and obligations of the state which imply the absence of the rule of law which is binding in the fulfillment of human rights of the poor. Consequently, the rights of the poor are often prone to be broken by the policy makers. In addition, this approach also looked at the public, especially the poor as a passive party so that their awareness and ability to assert their rights do not need to be increased. Therefore, it is not surprising that the empirical evidence shows that the impact of this approach to poverty reduction in the long term is not too significant.

Therefore, the poverty reduction agenda should be placed within the framework of the rights-based approach rather than the needs-based approach. The rights-based approach contains the State's obligation to respect, protect, and fulfill the basic rights of the poor either rapidly or gradually. This rights-based approach confirms all elements of the State, especially the executive, legislative, and judicial institutions for the realization of the basic rights of the poor with all power and progressively to utilize all available resources.

This rights-based approach was adopted by Indonesia through the Poverty Reduction Strategy (PRSP) formulated by the Committee on Poverty Reduction. PRSP document acknowledges that poverty as a multidimensional problem that is not only measured in revenue, but also related to the proneness and the vulnerability of the person or group of people, both men and women, to be poor, as well as the non-fulfillment of the basic rights of poor people to maintain and develop a dignified life.

The PRSP document defines poverty as a condition where a person or a group of people, men and women, are unable to meet their eligible basic rights to take and develop a dignified life. The document also mentions that the basic rights encompass the rights to food, housing, education, health, jobs, clean water, land, natural resources and the environment, security from treatment or the threat of violence, and the rights to participate in socio-political activities, both men and women (PRSP, 2004).

Poverty Reduction Committee uses the rightsbased approach because income or consumptionbased approach is proven to not touch the root cause of the problem of poverty and a lack of recognition and respect for sound and fundamental rights of the people. Therefore, solving the problem of poverty should be based on a sound understanding of the poor, and the respect, protection and fulfillment of their basic rights, namely the social, cultural, economic, and political rights.

\section{2) Poverty Conception from Human Rights Point of View}

Poverty cannot be denied has limited the freedom of men and reduce human dignity (UNDP, 2000). Therefore, there are two important things that must be realized if it is to understand the phenomenon of poverty properly. First, if poverty is limited only as a purely economic phenomenon, then the attributes of poverty should not be limited only at low levels of income, but also at the policy 
of allocation of economic resources. Low income is just one of the causes of poverty. The existence of policy mistakes and errors in the allocation of resources can be a major cause of poverty, especially in developing countries like Indonesia.

The study result of the Poverty Analysis Team of the World Bank Office in Jakarta (2006) confirms the reliability of the above arguments. The results of the study found that national poverty rates hide a large number of residents who live just above the national poverty line. That is, many residents of Indonesia are prone to be poor. Nearly $42 \%$ of all Indonesian people live among the poverty line of 1 USD and 2 USD per day indicating a remarkable aspect of poverty that has occurred in Indonesia. Another important finding in terms of non-income poverty is a more serious problem than poverty in terms of income. Non-income poverty is among others related to high malnutrition, the level of maternal health continues to deteriorate, education result weakness, low access to clean water and sanitation, especially among the poor.

Second, poverty as an economic problem does not mean that economic factor as a key factor causing poverty. For example, discrimination of race, religion, ethnicity, or other reasons could be a factor in delays in access to economic resources. In this context, the lack of access to economic resources only plays an intermediary role. The main cause lies precisely in the actual practices of the socio-cultural and political-legal framework that allows the cases of discrimination against individuals or specific groups.

Thus, although poverty is broader than simply have the sufficient income, but the definition of poverty based on human rights still referring to the condition of non-fulfillment of human rights without ending poverty linkage with economic resource constraints faced by a person. Therefore, in the context of human rights, poverty is defined as a condition characterized by a sustainable or chronic deficiency over resources, capabilities, choices, security and power necessary for the enjoyment of decent standard of living and civil, cultural, economic, political, rights and other rights (UN, 2001). This indicates that poverty is considered as a lack of basic capabilities of a person to live with dignity (UN, 2001).

In fact, Sengupta (2008) - former independent expert for human rights and extreme poverty defines poverty (the extreme one) as a combination of income poverty, human development poverty, and social exclusion. It also expressed by Narayan (2000), which asserts that the welfare is more than just wealth because a good quality of life includes five things, namely material wellbeing, body welfare, social welfare, have a security guarantee, and have the freedom to choose and act.

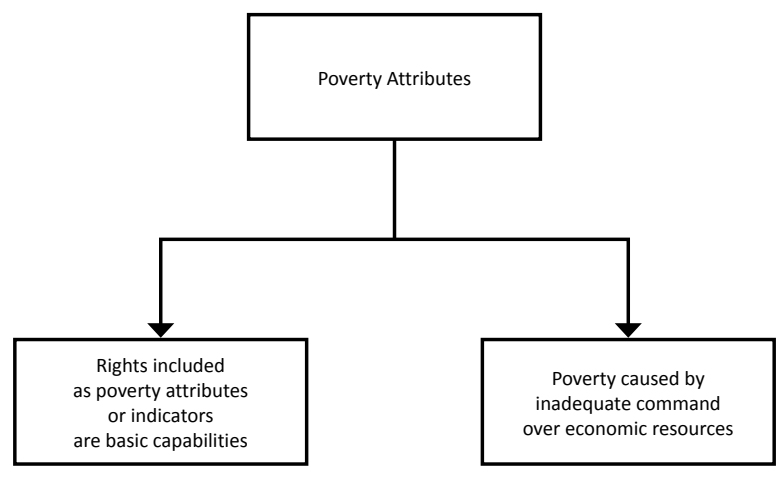

Figure 1. Poverty Attributes in Human Rights Perspective Source: OHCHR, 2004

On that basis, then poverty can be seen as the non-fulfillment of human rights condition related to the basic capabilities. The capability failure to function is an attribute inherent in poverty. However, not all capability failures can be categorized as a poverty attribute. Only the capability according to the poor as a basic capability that can be counted as a sign of poverty. However, the definition and elements of basic capabilities may vary among groups that exist within a system of society or community.

There are two prerequisites cases of nonfulfillment of human rights that can be considered as poverty, namely (i) components of human rights which are considered as basic capabilities; and (ii) the main cause of non-fulfillment of human rights is driven by command error in exploiting economic resources. However, a grouping of such poverty is not intended to negate the principle of integrity (indivisibility) between rights and still assume that all rights are equally important. The principle of integrity does not mean that all social phenomena must be defined by reference to all the rights. The principle truly only demands an inclusive strategy in addressing the problem of poverty.

Furthermore, the UN High Commissioner for Human Rights (2004) divides the intersection of human rights and poverty into three channels, namely constitutive relevance, instrumental relevance, and constrained-based relevance. First, human rights said to have constitutive relevance when poverty fueled by the lack of basic capabilities and policy mistakes on the usage of economic resources. Related to constitutive relevance, Osmani (2005) describes poverty as a form of denial of human rights. Constitutive relevance refers to the condition or attribute that is inherent in a person that can be regarded as poor. In this case, poverty is defined as a condition of loss in many cases where such a loss is considered as a form of denial of human rights (Osmani, 2005). Osmani (2005) further explains that by using logic flow (i) poverty can be seen as a form of failure to achieve basic capabilities; (ii) Most of the Human Rights may be 


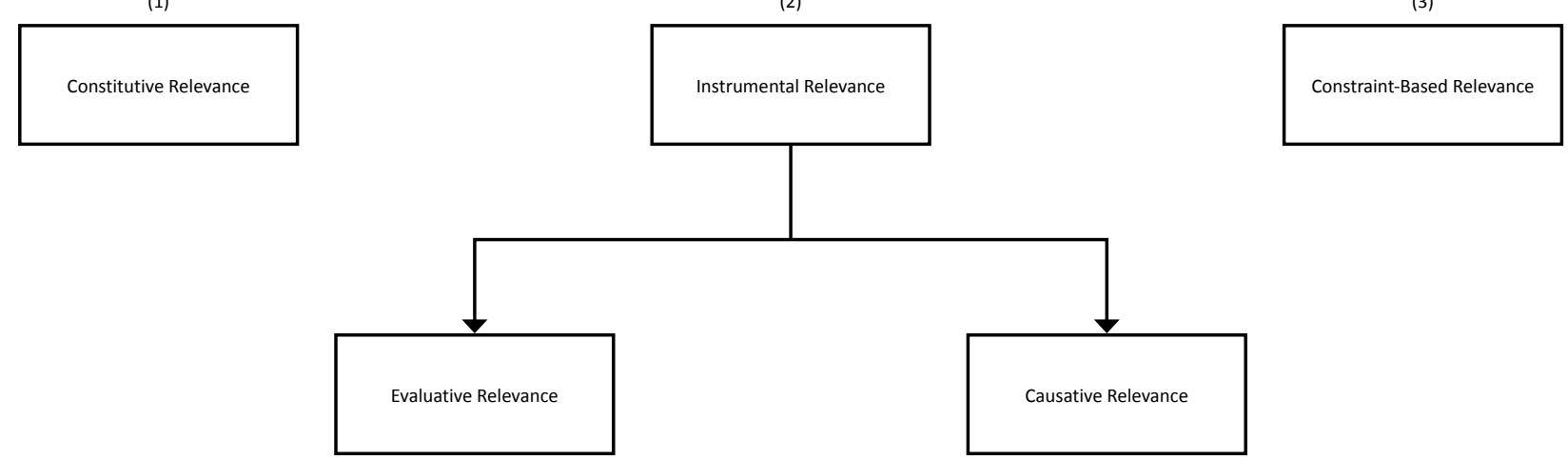

Figure 2. The Linkage of Human Rights and Poverty Source: OHCHR, 2004

claimed as the capabilities of the right to certain basic capabilities; and (iii) poverty therefore can be interpreted as a failure to comply, or rejection of a number of human rights.

Second, if the poverty status does not meet these two prerequisites in constitutive relevance, then human rights still have an affinity with poverty in the form of instrumental relevance. Instrumental relevance refers to the mechanism of causation (causal mechanism) which creates a condition known as poverty. Instrumental relevance views the rejection of human rights as the cause of poverty. For example, the poor get inhumane treatment, discriminated, stigmatized, and with restricted access to resources so that they are difficult to get out of the vicious circle of poverty. Instrumental relevance focuses on certain conditions that are the main cause of poverty. Instrumental relevance has two forms: (i) causative relevance; and (ii) evaluative relevance.

Causative relevance comes from the idea of Amartya Sen related to hunger. Sen (in Osmani, 2005) concluded that the famine never happens in democratic countries with the reasonable level of civil and political freedoms, especially with the freedom of the press that is relatively open to criticize the authority. In this context, civil and political rights are said to play an important causative role in preventing poverty as a result of famine. While the evaluative relevance stems from the idea that the analysis of poverty requires social evaluation in various aspects. For example, when it will define and derivate poverty indicators that are considered as the basic capability, needed a social consultation process that is truly participatory. Such process may not likely happen unless there is a fulfillment of certain relevant civil and political rights in the case. In this context, all of these rights are said to have evaluative relevance to poverty although these rights are not human rights indicators.

Third, constraint-based relevance. Human Rights is related to poverty if an action or a measure is taken to overcome poverty using the procedure that is not justified. For example, if a country with a high population but a very limited resource intends to control the population as part of a poverty reduction strategy, it is still not allowed to pursue policies that are cruel like forced sterilization program that violates personal integrity and privacy. In essence, a right which does not have a constitutive or instrumental relevance remains correlated to the nature and content of poverty reduction strategies with a way to set aside certain actions when not allowed (Osmani, 2005).

\section{3) Human Rights-Based Poverty Eradication Strategy}

Each country, both developing countries and developed countries, certainly have a poverty reduction strategy document. Unfortunately, this document generally uses conventional income. The approach is based on income or consumption-based approach. Human rights are integrated into national poverty reduction strategies. Although there are some rights included, yet human rights approach is not described in detail in the national poverty reduction strategy document.

In general, human rights-based poverty reduction strategy requires three main things. First, the main points of the content of the poverty reduction strategy document list the rights that could be considered as a basic capability. In addition, the State should affirm its commitment in terms of control of economic resources. Management of economic resources must be allocated appropriately and effectively by setting the poor as a priority. In terms of the limited economic resources, the State must prioritize the fulfillment of basic rights of the poor by designing programs that are low cost but effective in helping the poor out of poverty.

Therefore, policymakers need to identify groups of people who truly suffer from inadequate achievement of basic capabilities to function. Whatever the method used to identify the poor, 

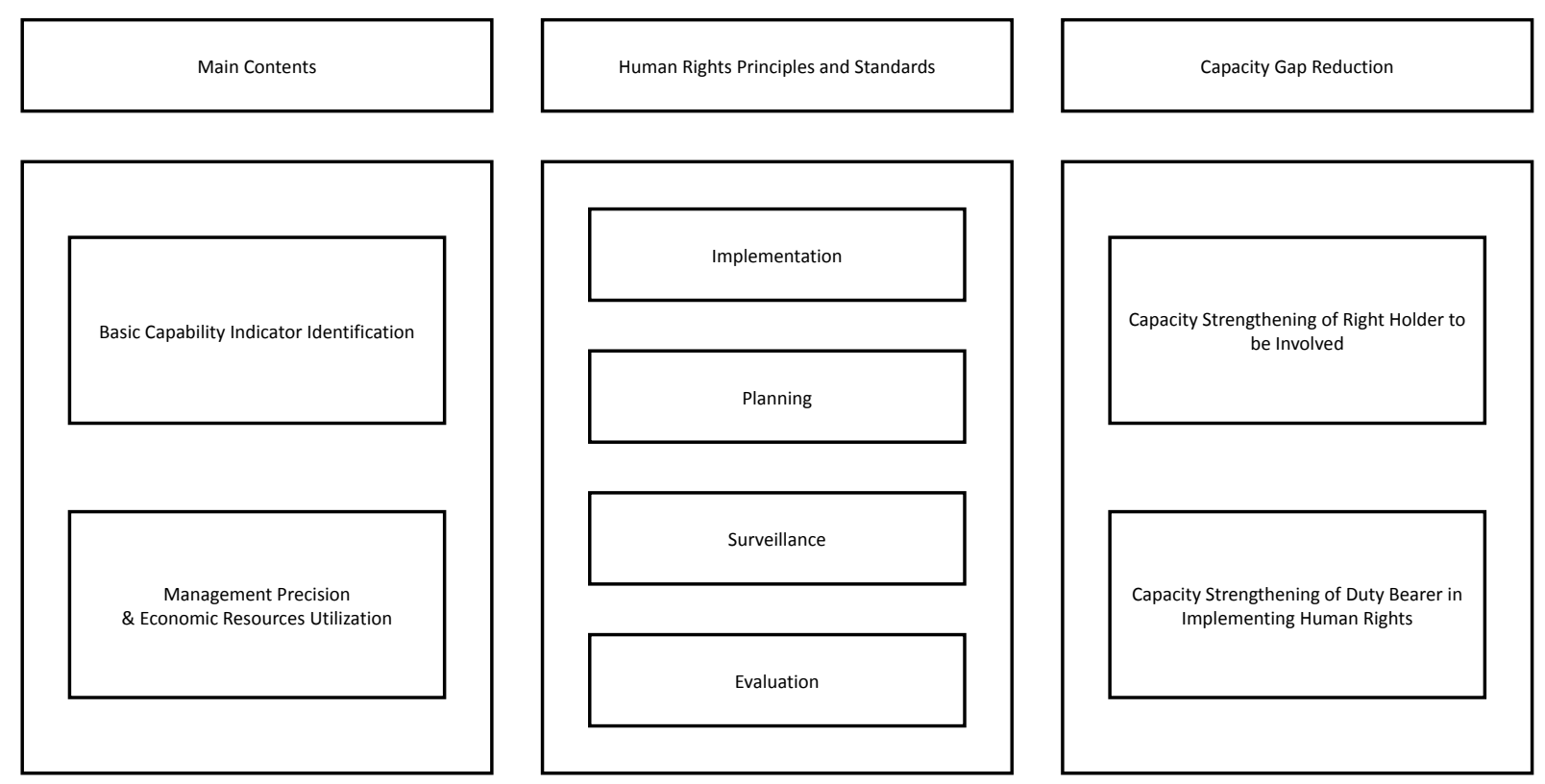

Figure 3. Human Rights-Based Poverty Eradication Strategy

human rights-based approach requires two specific considerations. First, identification of the poor does not only aim to obtain data on the number and percentage of people in the population but more than that, it is also to make sure who the poor are and how poor they are. Second, special efforts should be made to identify who among the poor people are suffering and marginalized (such as humiliation of women, or people living with HIV/AIDS, or the elderly, persons with disabilities, or those who suffer from race or religion discrimination). When the availability of resources is limited, then these groups should get primary attention. It is necessary for the sake of equality, which is an important principle in the human rights approach.

The next stage is the mainstreaming of human rights principles and standards into all stages of poverty reduction policies. The principles of human rights as universal and inalienable (universality and inalienability), can not be divided (indivisibility), interdependent and related (interdependence and interrelation), equality and non-discrimination (equality and non-discrimination), transparency, participation, accountability, and empowerment to be integrated from the planning stage to the evaluation of policies. In addition to the human rights principles, human rights standards are also an integral part in a human rights-based poverty reduction policies. Human rights standards are the normative content of each right as availability, accessibility, quality, acceptability, and others.

Finally, strengthening the capacity of stakeholders obligation (duty bearers) and holders of rights (right holder). This phase seeks to address the structural imbalances that affect the poor, offset power and increasing control over decisions and resources that determine the life quality of the poor. This phase is needed to increase the capacity of rights holders, especially the poor in the dyeing process of policy formulation that will affect their lives. Some participatory poverty reduction policies not running is often due to the lack of capacity of the poor. Even so, if the level of education of the poor people is low. In terms of stakeholder obligations, this phase is intended to increase the capacity of the government to analyze the most marginalized groups and strengthen the government accountability in institutionalizing community participation in the design and implementation of poverty reduction policies.

\section{ConClusion}

\section{A. Conclusion}

In the context of human rights, poverty is defined as a human condition characterized by a sustainable or chronic deficiency over resources, capabilities, choices, security and power necessary for the enjoyment of the standard of living and civil, cultural, economic, political rights and other rights. There are two prerequisites on the cases of human rights $\mathrm{n}$ can be counted as poverty, namely (i) components of human rights which included the basic capabilities; and (ii) the main causes of non-fulfillment of human rights is due to mismanagement and the allocation of economic resources. Furthermore, the intersection of human rights and poverty can be divided into three connections, namely the constitutive linkage, instrumental, and constraints-based. Related the strategy for poverty reduction, human rights-based 
poverty reduction strategy requires three main things. First, the main points of the content of the poverty reduction strategy document list the rights that can be considered as the basic capabilities and management of economic resources must be allocated appropriately and effectively by setting the poor as a priority. Second, the mainstreaming of human rights principles and standards into all stages of poverty reduction policies. Finally, strengthening the capacity of stakeholders obligation (duty bearers) and holders of rights (right holder).

\section{B. Suggestions}

Referring to the above description, this study recommends three things as follows. First, considering that poverty is a human rights issue, the government needs to mainstream human rights into poverty strategies, policies, and eradication programs. Second, the government, especially the National Team to Accelerate Poverty Eradication (TNP2K) is deemed necessary to expand the conception of poverty by inserting a human rightsbased approach in its policies. Third, human rights activists need to define and lower the fundamental rights which are categorized as basic capabilities and formulate poverty due to mismanagement and the allocation of economic resources.

\section{ACKNOWLEDGEMENT}

The author would like to express his gratitude to the researchers in the Division of Study and Research of the National Commission on Human Rights who were willing to spare their time to discuss the correlation between human rights and poverty in a more operational and contextual language. The author would also like to express his infinite gratitude to the Editorial of Jurnal Bina Praja, including Mitra Bestari, for continuously reminding the author regarding the writing format and the substance of journal article that meets the criteria of Jurnal Bina Praja.

\section{REFERENCES}

Alkire, S., Chatterjee, M., Conconi, A., Seth, S., \& Vaz, A. (2014). Global Multidimensional Poverty Index 2014.

Budiantoro, S., \& Martha, L. F. (2012, December). Paradoks Kekayaan Berlipat dan Indeks Kelaparan yang Mandek. Prakarsa Policy Review, 1-4.

Commitee on Economic Social and Cultural Rights. (2001). Statement Adopted by the Committee on May 4th 2001 on Poverty And The International Covenant. Geneva.

Directorate General of Budget Ministry of Finance (DJA Kemenkeu). (n.d.). Anggaran Kemiskinan, 2009-2014. Retrieved March 1, 2016, from http://www.anggaran.depkeu.go.id/dja/ athumbs/apbn/KEMISKINAN.pdf

Donnelly, J. (2009). Human Rights. In J. S. Dryzek, B. Honig, \& A. Phillips (Eds.), The Oxford Handbook of Political Theory. Oxford: Oxford University Press. http://doi.org/10.1093/ oxfordhb/9780199548439.003.0033

Haughton, J., \& Khandker, S. R. (2009). Handbook on Poverty and Inequality. Washington, DC: The World Bank. http://doi.org/10.1596/978-08213-7613-3

Kakwani, N. (2006, December). Poverty and Wellbeing. Poverty in Focus, 20-21.

Kanbur, R. (2006, December). Measuring Poverty with a Changing Population. Poverty in Focus, 18-19.

Komite Penanggulangan Kemiskinan. (2004). Strategi Nasional Penanggulangan Kemiskinan (SNPK). Kementerian Koordinator Kesejahteraan Rakyat RI.

Moser, C. (2004). Rights, Power, and Poverty Reduction. In R. Alsop (Ed.), Power, Rights, and Poverty: Concepts and Connections (A working meeting sponsored by DFID and the World Bank March 23-24, 2004) (pp. 29-50). London: The International Bank for Reconstruction and Development/The World Bank and the Department for International Development.

Narayan, D., Chambers, R., Shah, M. K., \& Petesch, P. (2000). Voices of the Poor: Crying Out for Change. New York: Oxford University Press.

Office of the United Nations High Commissioner for Human Rights (OHCHR). (2004). Human Rights and Poverty Reduction: A Conceptual Framework. New York and Geneva: United Nations.

Office of the United Nations High Commissioner for Human Rights (OHCHR). (2012). Principles and Guidelines for a Human Rights Approach to Poverty Reduction Strategies. United Nations High Commissioner

Osmani, S. R. (2005). Poverty and Human Rights: Building on the Capability Approach. Journal of Human Development, 6(2), 205-219. http:// doi.org/10.1080/14649880500120541

Saparini, P. H. (2013). Salah Arah Pembangunan, Salah Kaprah Pengentasan Kemiskinan | Bina Desa. Retrieved June 19, 2016, from http:// binadesa.org/salah-arah-pembangunan-salahkaprah-pengentasan-kemiskinan/

Sen, A. (1999). Development as freedom. New York: Anchor Books.

Sengupta, A. (2008). Report of the Independent Expert on the Question of Human Rights and Extreme Poverty.

Statistics Indonesia (BPS). (2015). Statistical Yearbook of Indonesia 2015. (Sub-directorate of Statistical Compilation and Publication 
\& Sub-directorate of Statistics Indicator, Eds.). Jakarta: Statistics Indonesia (BPS). Retrieved from http://bps.go.id/index. php/\%0Dpublikasi/1045

Sumner, A. (2007). Meaning versus measurement: why do "economic" indicators of poverty still predominate? Development in Practice, 17(1), 4-13. http://doi. org/10.1080/09614520601092485

The World Bank. (2007). Era Baru dalam Pengentasan Kemiskinan di Indonesia. Jakarta.

The World Bank. (n.d.). World Development Indicators (WDI). Retrieved March 1, 2016, from http://data.worldbank.org/indicator UNDP. (2000). Human Development Report 2000. New York: Oxford University Press.

UNDP. (1997). Human Development Report 1997. New York: Oxford University Press.

World Bank. (2015). A Measured Approach to Ending Poverty and Boosting Shared Prosperity: Concepts, Data, and the Twin Goals. Policy Research Report. Washington, DC: Publishing and Knowledge Division, The World Bank. Retrieved from https:// openknowledge.worldbank.org/bitstream/ handle/10986/20384/9781464803611.pdf 